\title{
打ち水の効果に関する社会実験と 数值計算を用いた検証 SOCIAL EXPERIMENT OF WATARING AND NUMERICAL VERIFICATION
}

\author{
狩野学 $1 \cdot$ 手計太一 $2 \cdot$ 木内豪 $3 \cdot$ 榊茂之 $4 \cdot$ 山田正 5 \\ Manabu KANO, Taichi TEBAKARI, Tsuyoshi KINOUCHI, Shigeyuki SAKAKI and Tadashi YAMADA
}

\author{
1 学生員 中央大学大学院 理工学研究科 土木工学専攻（广112-8551 文京区春日 1-13-27） \\ 2 正会員 工修 独立行政法人士木研究所 水工研究グループ JST/CREST (テ305-8516 つくば市南原 1-6) \\ 3 正会員 博士 (工学) 独立行政法人士木研究所 水工研究グループ 主任研究員 (テ305-8516 つくば市南原 1-6) \\ ${ }^{4}$ 正会員 Ms. Pub. Adm. 国土交通省 関東地方整備局 荒川下流河川事務所 調查課 課長（广115-0042 北区志茂 5-41-1) \\ ${ }^{5}$ 正会員 工博 中央大学教授 理工学部 土木工学科（广112-8551 文京区春日 1-13-27）
}

\begin{abstract}
The large-scale social experiment, which many citizens including media representative participated for evaluating the effects of the watering on the "Heat Island Effect", was carried out in Tokyo Metropolitan in Aug. 25 2003. About 14000l. water were sprinkled for about 20 minutes from noon. Air temperature and humidity were measured by moving observation system and fixed observation system at watering area in Eastern Tokyo. After the watering, the air temperature difference between outside and inside of watering area increases, and its difference was about $0.5^{\circ} \mathrm{C}$. Temperature of watering area is lower than the temperature of outside area of watering after the watering. The effect of the watering was verified using the numerical simulation based on MM5. As a result of this analysis, air temperature degreased $2-2.5^{\circ} \mathrm{C}$ in watering area after the watering.
\end{abstract}

Key Words : watering, irrigation, meso scale simulation, social experiment, heat island

\section{1.はじめに}

近年のヒートアイランドに代表されるような都市気候 の変化が熱環境を悪化させ, 突発性の集中豪雨を誘発さ せていると考えられている. そのヒートアイランド緩和 のために様々な方法が考えられている. 水辺や緑地の増 加, アスファルト舗装の改良など, 行政や研究機関など を中心に実験が行われ，さらには実際の施政として行わ れている.

例えば, 武若ら 1)都市内河川において係留気球を用い た気象観測を行い，気温の低下量は大気が河川上で交換 した熱量と相関がある事, 河川が気温低減に与える影響 範囲は堤防から風下に約 $150 \mathrm{~m}$ までである事を明らかに している. また, 三上ら 2は東京都新宿区, 新宿御苑内の 御苑内外で温湿度計を用いた気象観測を行い, 緑地の気 温が夜間では周辺より約 $3^{\circ} \mathrm{C}$ 低く, 緑地からの冷気がにじ みだす効果で, 周囲は最大で $2.5^{\circ} \mathrm{C}$ 周辺の気温より下がる 事を明らかにした. さらに, 木内ら 3)は新潟県長岡市にお いて消雪パイプを用いた散水実験を行い，道路散水が路 面温度の上昇を抑える事により熱環境の緩和に有効に機 能すること等を明らかにしている.

欧米では芝生や庭園への散水という意味での irrigation の効果によって気温が低減することは一般的
に認識されており，それらに関する研究が進んでいる.

日本では，夏の暑い日に庭や道端，道路に水を撒き， その水が蒸発してその周辺の温度を吸収してくれるとい うことは江戸時代から知られていた，さらに日中よりも 朝や夕方に水を撒く方が効果的であることも理解されて いた. その頃から, 江戸の人々は「水」の重要さに気づ いていたため,「打ち水」には米のとぎ汁などの二次利用 水を使用していた. さらに, 江戸中に張り巡らされた側 溝の水は, 火災時の消火用水や洗い物などに使われると ともに打ち水にも使用されていた.「打ち水」は気温低減 のためは然ることながら, 神輿が通る際, 神様が通る道 に埃をたてないようにという意味もあった.

\section{2.「社会実験」としての大江戸打ち水大作戦}

\section{（1）社会実験とは}

「社会実験」とは, 地域が抱えている問題を解決する ため，市民が自分で新しい施策を考え，実際に体験する ことで，施策を実施するかどうかの判断をすることであ る. 社会実験を実施することで，有効性が高いと思われ る施策について，その効果が把握できるとともに問題や 課題が明確となる. さらに，実験を通じて地域住民や関 
表-1 打ち水開催場所における各参加者数と打ち水量

\begin{tabular}{|c|c|c|c|}
\hline \multicolumn{4}{|c|}{ 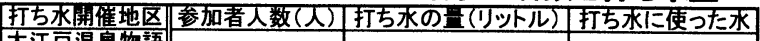 } \\
\hline $\begin{array}{l}\text { 大江戸温泉物語 } \\
\text { (東京都江東区) }\end{array}$ & 150 & 500 & 温泉の残り湯 \\
\hline $\begin{array}{c}\text { 大鵬部應 } \\
\text { (東京都墨田区) }\end{array}$ & 40 & 60 & 雨水 \\
\hline $\begin{array}{c}\text { 金春通り } \\
\text { （東京都中央区） }\end{array}$ & 200 & 350 & 銭湯の残り湯 \\
\hline $\begin{array}{l}\text { 都庁前都民広場 } \\
\text { (東京都新宿区) }\end{array}$ & 180 & 600 & 雨水，下水再生水 \\
\hline
\end{tabular}

係者が施策を体験することによって合意形成の促進に役 立つことから，今後の施策展開を速やかに行うことが期 待できる.

例えば，最寄駅の駐車場に自動車を駐車し，公共交通 機関に乗り換えて通勤する「パーク・アンド・ライド」 の社会実験は，日本のみならず世界各地で行われ，その 実験結果を基に実際に施行されている例が多数ある. 他 にも交通の分野では, ライドシェアリング(相乗り),ETC, ITS などの社会実験が数多く行われている.

\section{（2）大江戸打ち水大作戦}

2003 年 3 月に京都で開催された第 3 回世界水フォーラ 厶の閣僚宣言の中に「世界の水問題を解決する一つの重 要な要素として，近隣社会の取り組みが大事である」と 盛り込まれた. これを出発点として, NPO 第 3 回世界水 フォーラム事務局が主体となり，「ヒートアイランド現象 の緩和」という目的のために, 風呂の残り水や雨水や再 生水など水の二次利用, 再利用を促進させる試みとして 「大江戸打ち水大作戦」が生まれた. 主に 5 つの NPO 団体が参加し，国土交通省，環境省，東京都などが後援 となった。

「江戸の知恵に学べ」の号令の下, NPO を中心として, 「んなの手で灼熱の東京の気温を $2^{\circ} \mathrm{C}$ 下げよう」と 100 万人の参加者を目標にホームページの作成，ラジオ，テ レビなどを通じての PR 活動，打ち水参加への呼びかけ が約 1 ヶ月間行われた。

事務局がイベントとして主催した「打ち水」の開催場 所は 4 箇所（表-1），そして重点地区として東京都墨田 区東向島 1 3 丁目（図-1，図-2）において集中的な気温 と湿度の測定，サーモグラフィーを用いた地表面温度の 測定を行った. 本稿では特にその重点地区についての観 測結果を示す。

本社会実験への最終的な参加者数については事務局が 次のように算定した．まず無作為の電話による聞き取り 調査を行い，「大江戸打ち水大作戦」を知っている人の割 合 $22.2 \%$,「大江戸打ち水大作戦」に参加した人の割合 8.5\%が算定された. この值を基に，東京 23 区内の世帯 数 3,995,219 から打ち水参加者数を約 340,000 人とした.

このように，東京 23 区内という広大な地域，340,000 人という多数の市民が参加した社会実験はこれまでには 無かった試みであると思われる.

\section{3. 実験概要}

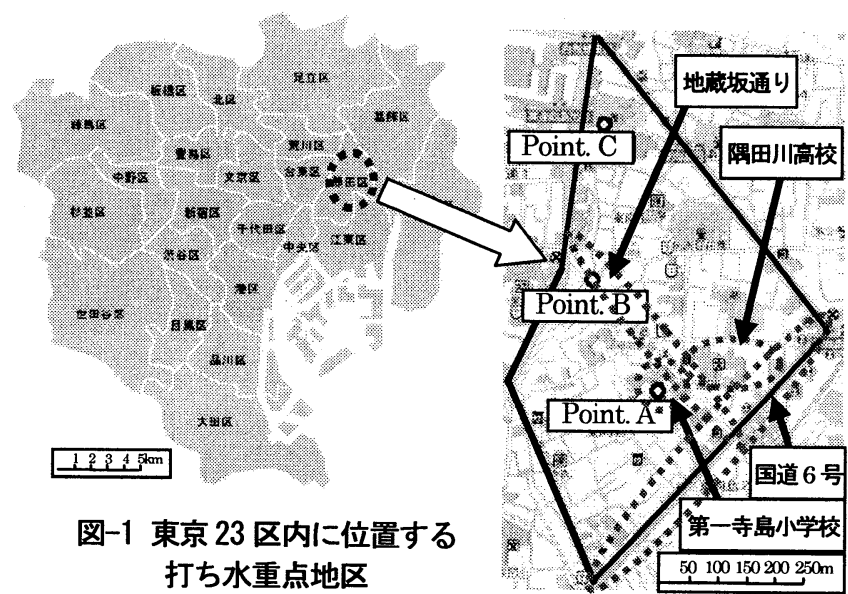

図-2 打ち水地区の地図

（墨田区東向島 1 3 丁目）

本実験は, 2003 年 8 月 25 日 11:00 13:00 までの間, 東京都墨田区東向島 1 3丁目で行われた. 観測対象域を 図-1, 図-2 に示寸。この地域は東京の 23 区内東部に位 置し，いわゆる下町と言われる地域である。この地域で は墨田区が雨水貯留施設の設置を推進・支援している. 打ち水は二次水の有効利用手段の一つであるという理由 から，この地域で実験を行うに到った.

打ち水は，図-2 に示寸黒線で囲まれている地区（東向 島 1〜3丁目）で $12: 00$ より約 20 分〜 25 分間行った. 特 に，第一寺島小学校と墨田川高校はイベントとしてそれ ぞれ 500 リットル， 600 リットルの水が撒かれ，地蔵坂 通りは商店街の協力により約 1,700 リットルの散水が行 われた. また国道 6 号沿いでは，散水車を使い約 $600 \mathrm{~m}$ 間を 20 分程かけて 11,000 リットルの水を撒いた. 打ち 水に用いた天水の水温は，この地域の日平均気温（約 $\left.27^{\circ} \mathrm{C}\right)$ とほぼ同じであった。このような場合，水は貯熱 より潜熱効果の方が遙に大きいと考えられるため, 水温 の解析は行わなかった．観測は以下の 3 種類を行った.

\section{（1）定点観測}

図-2 に示寸第一寺島小学校 (Point. A)，地蔵坂通り (Point. B), 白䰀神社 (Point. C) で定点観測を行った. 各観測ポイントの地上から約 $1.5 \mathrm{~m}$ の地点に通風式温湿 度計を設置し，気温，相対湿度の計測を行った．また観 測 Point. C では風速計を設置し風速の測定も行った.

また，打ち水エリア外のデータとして，東京都台東区 役所（打ち水地域加東南東方向に直線距離約 $3 \mathrm{~km}$, 地 上 $43 \mathrm{~m}$ 地点に器材設置) において計測している気温, 相 対湿度，風速を用いた。 なお，今後台東区役所の気温を 外気温，相対湿度を外相対湿度と本稿では定義する。

\section{（2）移動観測}

打ち水区域を 10 分割し, 各エリアにおいて気温, 相対 湿度の移動観測を行った。測定機器はサーミスタ式温湿 度計 (Onset 社製) を用いた. 直射日光を避ける事及び, 観測機器のセンサ一付近での空気の循環を目的として観 測機材には強制通風措置を施した。 また定点観測と同条 


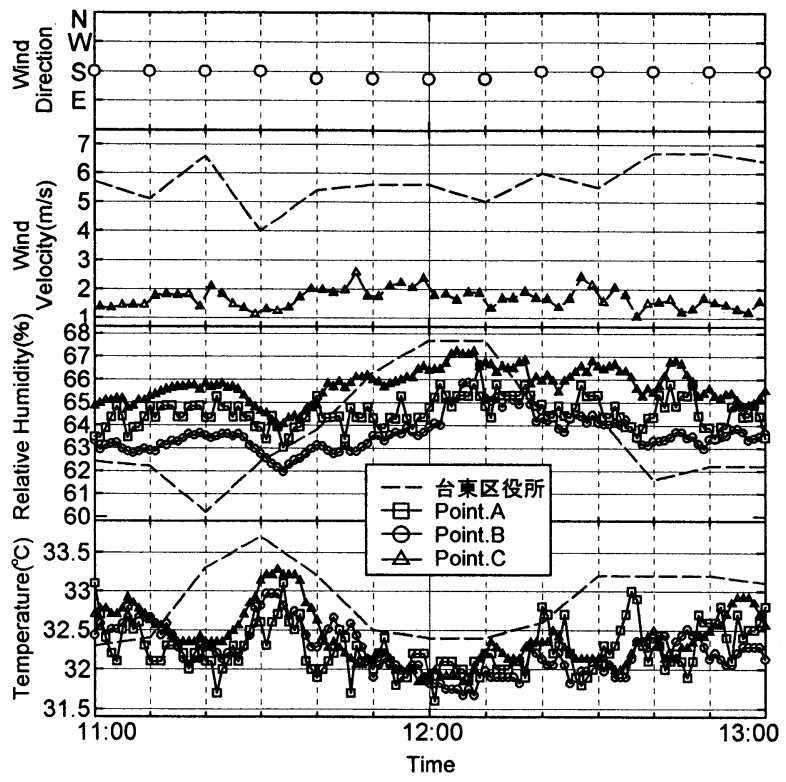

図-3 定点観測Point における気温，相対湿度，

風速，風向の時系列（観測Point. $A \sim C$, 台東区役所）

件下になるよう地上から $1.5 \mathrm{~m}$ 地点で計測を行った. また サーミスタ式温湿度計は事前・事後検定を行い，校正し たデータを解析に用いた. 移動観測中に, 打ち水個所を 地図上にプロットする作業，写真撮影も同時に行った。

\section{（3）熱画像観測}

ヘリコプターを飛揚させ, 上空から熱赤外センサー（日 本アビオニクス社製 TVS-600) で地表面温度の測定を 行った. 撮影は 15 分〜20 分に 1 回行った.

\section{4. 観測結果と考察}

\section{（1）実験当日の天気概況}

今夏は気温の低い日が続いていたが，観測日は関東地 方を太平洋高気圧が覆い，日中 $30^{\circ} \mathrm{C}$ を越す真夏日となつ た日であった. また, 観測時間中は, 7〜 $8 \mathrm{~m} / \mathrm{s}$ の南風が 吹く, 海風の非常に強い一日であった.

\section{（2）定点観測における気温，相対湿度}

Point. A，Point. B，Point. C，及び東京都台東区役所 における気温, 相対湿度, 風速, 風向の時系列を図-3に 示寸. 11:30 頃から 12:00にかけて打ち水地域の気温・外 気温の減少，相対湿度・外相対湿度の増加が起こる. 気 温低下時に南方からの風速が上昇している事から, 気温 の減少、相対湿度の増加は海風による海上の湿った相対 的に冷たい空気の流入によるのではないかと考えられる.

図-4に外気温と打ち水地点の気温差, 相対湿度の差(台 東区役所の值から打ち水エリアの值を引いた）の時系列 を示す. 12:00 にPoint. A における外気温との差が $0.5^{\circ} \mathrm{C}$, Point. B における外気温との差が $0.1^{\circ} \mathrm{C}$ 大きくなってい る事が分かる. また 12:00〜12:05 までの間に外相対湿度 差が Point. A, Point. B 共に 1.5\%程度下がっている事が 分かる.この気温と相対湿度の変動が打ち水によるもの

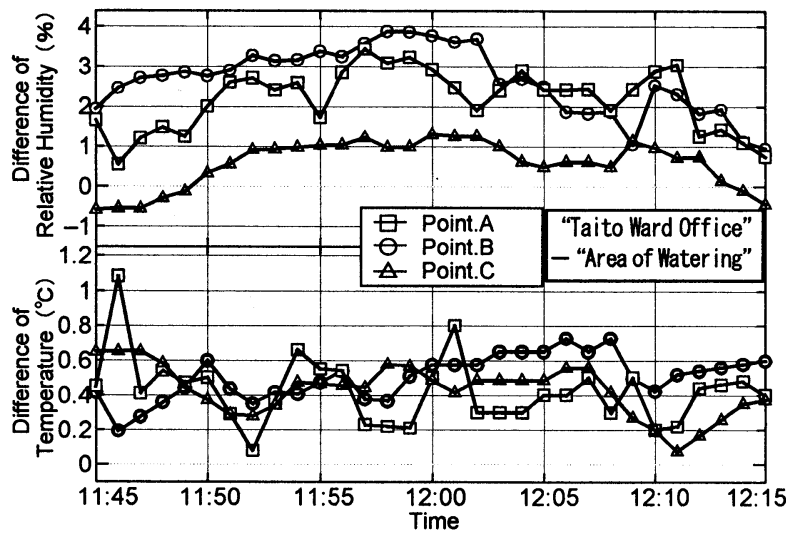

図-4 台東区役所と定点観測Point における気温, 相対湿度の差の時系列 (11:45 12:15)

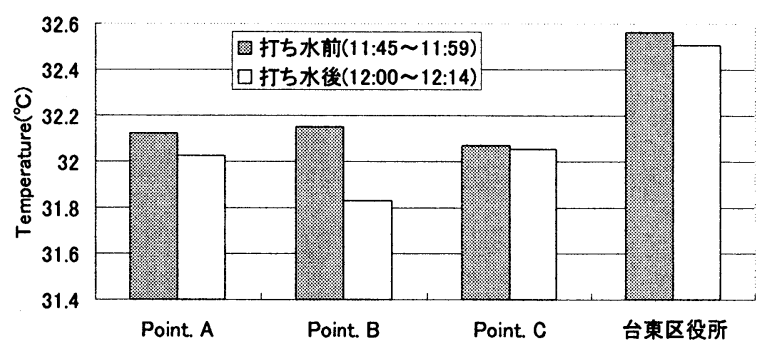

図-5 打ち水前後 15 分間の平均気温の比較

ではないかと考えられる. 図-5 は打ち水エリア及び，外 匃温の打ち水前後 15 分間 (12:00 を境として前後 15 分 間）の平均気温の比較を行ったものである. 打ち水前に 比べ, 打ち水後ではPoint. B で約 $0.3^{\circ} \mathrm{C}$, Point. A で $0.1^{\circ} \mathrm{C}$, Point. $\mathrm{C}$ で $0.01^{\circ} \mathrm{C}$ 程度気温が減少している事が分かる. 台東区役所でも気温の減少は起こっており, 総観規模で 気温の減少が起きていると言える. しかし，打ち水エリ アの気温低下量は外気温低下量より大きくこの差分が打 ち水の影響ではないかと考えられる. Point. B が他の 2 地点に比べ気温の減少が大きいのは，通りであるため風 が通りやすかった事, Point. B の通りでは打ち水量が 1,700 リットルと他地点に比べ多かったためではないか と考えられる.

\section{（3）移動観測による気温，相対湿度}

図-6, 図-7 は移動観測から得られた 11:00〜11:09 と 12:20〜12:29 における気温, 相対湿度の分布を示してい る. 打ち水前の 11:00 11:09 に比へ，打ち水後の 12:20 １2:29 では重点地域の第一寺島小学校, 地蔵坂通り, 墨 田川高校付近では, 気温の減少, 相対湿度の増加が起こ っている. 気温は $0.8 \sim 1.0^{\circ} \mathrm{C}$ 減少，相対湿度は $2 \sim 3 \%$ 上昇していた．海風の影響を除去するために，打ち水前 後で台東区役所との差を取ったのが図-8 と図-9 である. 図-8 は気温, 図-9 は相対湿度である. 打ち水地域の気温 は外気温より低い為, 打ち水を行う前でも全体的に低く なっているが，打ち水後は低温部分が増えている事が分 かる. 相対湿度も, 打ち水前は台東区役所に対して $5 \%$ ～ $0 \%$ 低かったが, 打ち水後は台東区役所より高くなる個所 もあった。

図-10 は図-8，図-9 それぞれについて差を取ったもの 


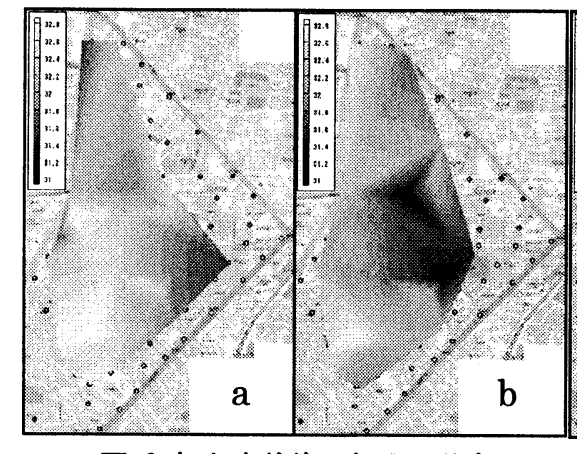

図-6 打ち水前後の気温の分布

$\left(\begin{array}{l}a: \text { 打ち水前[11:00 11:09] } \\ b: \text { 打ち水後[12:20 12:29] }\end{array}\right)$

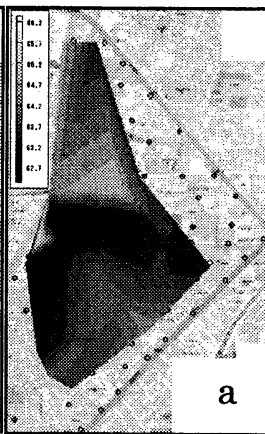

図-7 打ち水前後の相対湿度の分布

(a : 打ち水前[11:00 11:09]

$\left(\begin{array}{l}a: \text { 打ち水後[12:20 12:29] }\end{array}\right)$

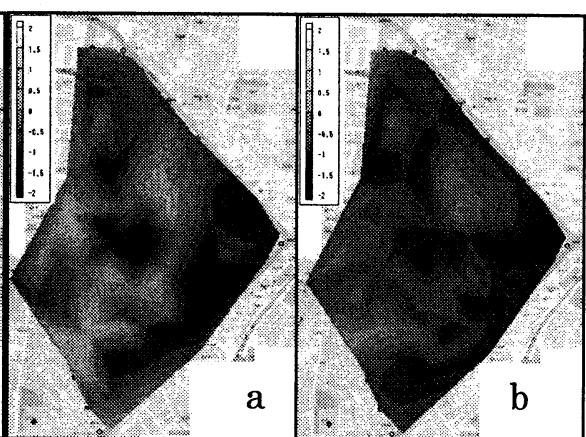

図-8 打ち水前後の外気温 （台東区役所）との差の分布 $a$ : 打ち水前, $b$ : 打ち水後 )

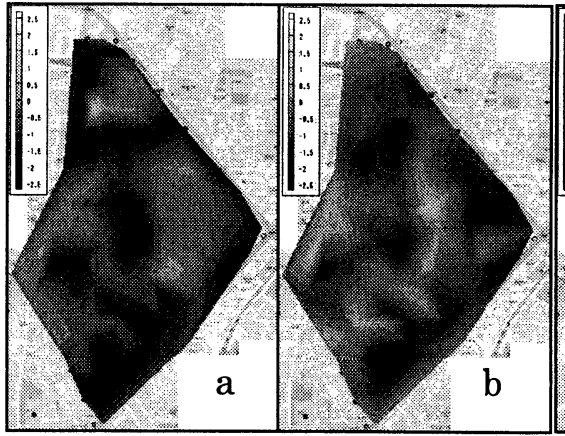

図-9 打ち水前後の外相対湿度 （台東区役所）との差の分布 ( $a$ : 打ち水前, $b$ : 打ち水後 )

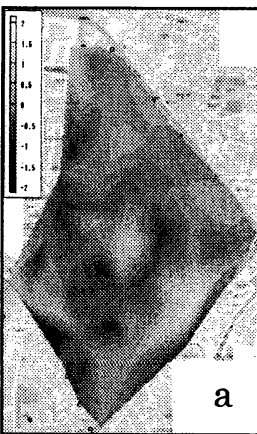

図-10 図-8, 図-9 の打ち水前後の差 ( $a$ : 気温, b : 相対湿度 )

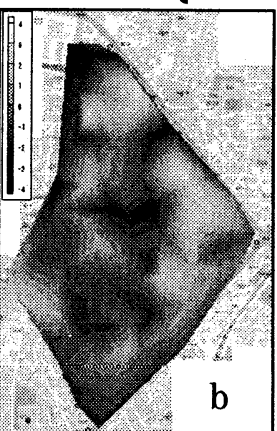

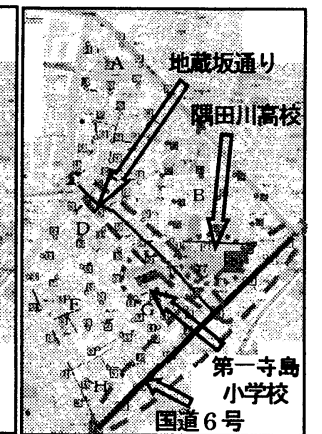

図-11 打ち水個所
である. また図-11 に移動観測班の調査から得られた打ち 水個所を示す. 重点地域である第一寺島小学校, 散水車 を用いて打ち水を行った国道 6 号沿いでは打ち水前に比 べて顕著に外気温との差が負に大きくなっている事が分 かる. また，測定エリア $\mathrm{H}$ や，測定エリア Aの9〜111 ら測定エリア C にかけては満遍なく打ち水がされている 為, 外気温との差は負に大きくなっている. 逆に測定エ リア Gから測定エリア $\mathrm{E}$ の南部では打ち水個所が少なく， 外気温との差は正に大きくなっている. 打ち水個所と外 気温との差が負に大きくなった場所はほぼ一致しており， その平均温度差は約 $-0.5^{\circ} \mathrm{C}$ であった. 逆に, 打ち水後の方 が外気温との差が正に大きくなった地点の平均温度差は 約 $0.3^{\circ} \mathrm{C}$ であり, 打ち水エリア全体での平均温度差は約 $-0.27^{\circ} \mathrm{C}$ であった.

\section{（4）熱赤外センサ一による地表面温度の測定}

図-12 は航空機から熱赤外センサーを用いて計測した 地表面温度の分布を打ち水前後で差を取ったものである

(打ち水前が 11:45, 打ち水後が 12:20). 図の左上の道 路（丸で囲ってある部分）は打ち水前より打ち水後の方 が地表面温度は上がっているのに対して, 図の右下の道 路（一点鎖線の丸で囲ってある部分）は打ち水後の方が 地表面温度は下がっている事が分かる. この温度が下が っている道路は, 散水車を用いて大々的に散水を行った 道路であり, 打ち水により表面温度の減少が起きたと考 える事が出来る.

\section{5. メソスケールモデルを用いた打ち水効果の算定}

打ち水を大規模に実施した場合のヒートアイランド軽 减効果を試算するため, メソスケールモデルによるシミ ユレーションを行った.

\section{(1) モデルの概要}

本研究で用いたシミュレーションモデルは, 米国ペン シルバニア州立大学で汎用の気象計算モデルとして開発 され, その後, NCAR (米国大気研究センター) におい てさらに改良された MM54)基本にした. ただし, MM5 を直接我が国のヒートアイランド現象のシミュレーショ ンに用いるには不都合な点がいくつかあったため, 下記 の改良を加えた5）6.

・複雑な都市の土地利用に適した地表面フラックスの算 定ができるように 1 計算メッシュ内の土地利用の混在 をパラメータ化する手法を導入した.

-土地利用情報として国土地理院が整備・発行する国土 数值情報（KS-200-1, 土地利用分類ごとの面積率デー 夕を使用) と細密数值情報（首都圏 1994 年版, 解像度 10m）を使用できるようにした.

•MM5 バージョン $2.12 に$ Noilhan and Planton ${ }^{7}$ の地 表面モデル（地表面の水分移動モデルと植物生理のモ デル, 以下 NP モデル) を新たに組み込んで地表面水 分量の変化を予測し, 地表面の水分量に応じた植生面 からの蒸散量や裸地面からの蒸発量の算出ができるよ うにした。 
- 接地層下面に土地 利用分類や時間に 応じた量の人工排 熱を潜熱フラック スと顕熱フラック スの形で与えられ るようにした。

\section{（2）打ち水効果の}

\section{算定条件}

打ち水の対象範囲 は東京 23 区全域とし た. このうち, 建物 用地では敷地面積の $40 \%$ 相当分, 道路用 地のうち, 不浸透面 の $50 \%$ 相当分を打ち 水可能域と想定した. また, 植生面・裸地 面では，70\%の面積 に打ち水が可能と設

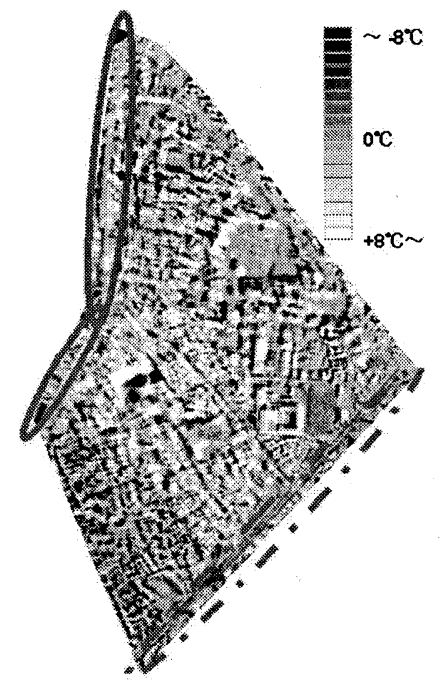

図-12 打ち水前後の 地表面温度の差

上図は，熱赤外センサーを搭載し たヘリコプターから打ち水エリア の地表面温度を測定し, 打ち水前 後でその差を取ったものである. 破線内は散水車を用いて大量に散 水した道路. 実線内は散水を全く 行わなかった道路. 破線内は実線 内よりも表面温度が下がっている ことが分かる.

定した. 残りの $30 \%$ では打ち水は無く, 刻々の土壌水分 量に応じた蒸発散が生じると仮定している.この想定に よれば，東京 23 区全体のほぼ $40 \%$ の面積（約 $265 \mathrm{~km}^{2}$ ） において打ち水が行われる勘定となる.

打ち水の時間帯は 11:30～12:30 と 17:30〜 18:30 の 2 ケースとした. 打ち水された地表面においては，バルク 式 ( $\beta$ 法) の蒸発効率 $\beta$ を一定值 $(=0.7)$ として与えた.

比較として, 土壌水分量の多寡の影響を見るための計 算も行った. 条件としては, 初期の土壌水分量が領域全 体で飽和水分量の $35 \%$ の場合, 東京 23 区内のみで飽和 水分量の $52.5 \%$ とした場合（5割増）及び圑場容量にほ ぼ等しくなる場合（飽和水分量の約 $81 \%$ ）の 3 ケースと した. 地表面モデル (NP モデル) の蒸発効率と含水率の 関係には次式 7) を用いた。

$$
\begin{aligned}
& E_{g}=\rho_{a}(1-v e g) \frac{H_{u} q_{s a t}\left(T_{s}\right)-q_{a}}{R_{a}} \\
& H_{u}= \begin{cases}0.5\left(1-\cos \left(\pi \frac{W_{g}}{W_{f c}}\right)\right), \text { if } W_{g} \leq W_{f c} \\
1, \text { otherwise }\end{cases}
\end{aligned}
$$

\section{（3）その他の設定条件}

土壌の種類は全域でローム層を仮定し, Noilhan and Planton 7) の上袞パラメータを与える. ただし, ロームに 対するパラメータのうち, 飽和含水率, 固場容量, しお れ点の含水率については中野8 8 を参考に, それぞれ0.68, 0.55，0.20 と設定した. 土地利用分類毎の緑被率（緑地 面積中で植生により占められている面積の割合）は，東 京 23 区を対象に東京都都市計画局が算出した值をもと

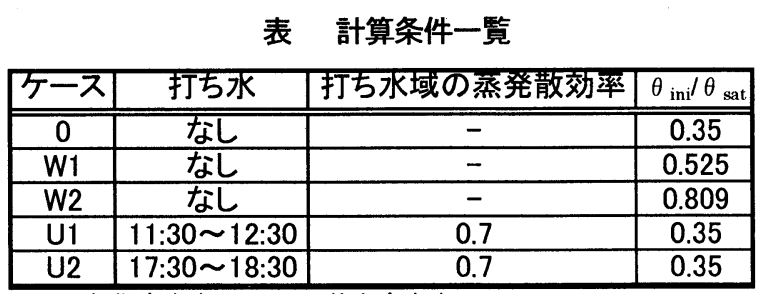

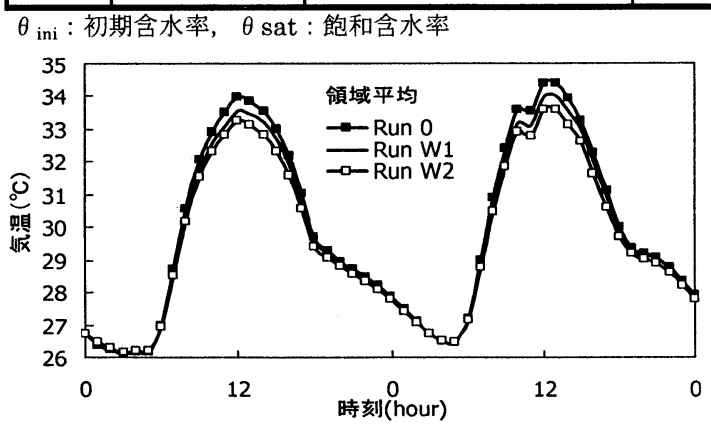

図-13 土壤水分の違いが地上気温に及ぼす影響

に土地利用分類ごとに推定し, 対象領域全域に適用した.

\section{（4）メソスケールモデルの適用結果}

\section{a) 計算条件}

計算対象領域は関東平野を含む $366 \mathrm{~km}$ 四方の母領域 と東京 23 区を含む $114 \mathrm{~km}$ 四方のネスト領域である. 母 領域の解像度は $6 \mathrm{~km}$, 計算メッシュ数は $61 \times 61$, ネス 卜領域は $2 \mathrm{~km}, 57 \times 57$ とした. 鉛直方向は $100 \mathrm{hPa}$ の 等圧面までを 25 層に分割した. この場合, モデル最下層 の厚さはおよそ $15 \mathrm{~m}$ となる. 母領域の初期条件, 境界条 件には計算対象日を含む NMC ( National Meteorological Center) の全球解析データを用いた. ネ スティングの手法には 2-way nesting を用いた. 雲モデ ルはなし，放射モデルには気温のみに依存した大気泠却 率を用いる Simple cooling を用いた. 土地利用条件とし ては，細密数值情報が整備されている地域では第 5 期 （1994 年版）の細密数值情報を使用し，それ以外の地域 では国土数值情報（1992 年版）を用いた.

以上の条件のもと, 打ち水効果をシミュレートする. シミュレーションは，1995 年 8 月 23 日 21 時〜 8 月 26 日 5 時を対象期間とした. 東京大手町地点 (AMeDAS) では 8 月 22 日に降雨が観測されているが, 計算対象期間 中は好天で雲が少なかった. 東京都, 埼玉県, 千葉県, 神奈川県の主要な AMeDAS 地点における計算対象期間 中の実測気温と計算結果 (メッシュ平均值, 地上 $1.5 \mathrm{~m}$ ) を比較したところ, 各地点とも気温の絶対值や最高気温 の発生時刻, 日変動のパターンは概ね良好に再現されて いる 5） 6)ことから，以下においては，前述してきた条件 設定により打ち水による気温低減効果および士壤水分の 違いが地上気温に及ぼす影響について試算する.

\section{b）土壤水分の影響}

東京のような大都会では蒸発面が少ないので土㙥乾燥 化の影響がそれほど大きくないと思われるが, 結果とし ては図-13 に示すように大手町のような都心であっても 


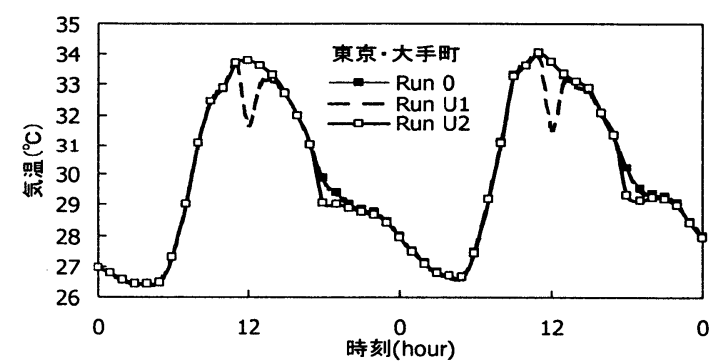

図-14 打ち水の有無による気温の違い（大手町）

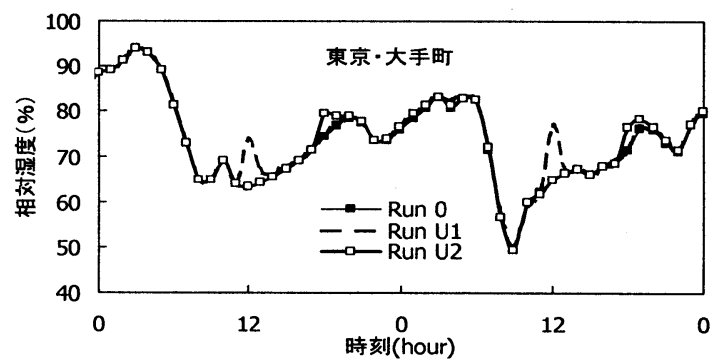

図-16 打ち水の有無による相対湿度の違い（大手町）

土袞水分量の多臭の影響を受けて地上気温（高さ $1.5 \mathrm{~m}$ ) に差が生じている．また，東京 23 区内の一定範囲（北緯 35.7 度〜35.8 度, 東経 139.75 度 139.85 度) の領域平 均值でみると大手町地点以上の違いが生じることがわか る. また, 相対湿度の違いは極わずかであった (図省略)。 気温低下量は様々なヒートアイランド対策に比肩する程 度 ${ }^{6}$ に大きく, 相対湿度の増加量は想像するほど大きく ないことがわかる.

c) 打ち水の効果

図-14 16には, 打ち水の有無と打ち水時間帯の違いに よる気温と相対湿度の違いを示す. 正午の打ち水により 気温低下量は大手町で約 $2.2^{\circ} \mathrm{C}$, 練馬で約 $2.4^{\circ} \mathrm{C}$ (いずれ も2 日分の平均）であった. また，正午打ち水よりは夕 方の方が相対湿度の増加量が小さいことがわかる.

正午打ち水による気温低下量空間分布 (Run U1 の気 温-Run 0 の気温）と Run U1 の風速ベクトルを図-17 に示す. 基本的には打ち水範囲全域とその周縁部で大き な低下効果が確認できる. また, 13 時には影響範用が拡 大している様子が見られる.

体感温度への影響という点で考えると気温の低下と湿 度の上昇は相反する効果をもたらすことから，効果的な 打ち水面の選択（高温化した地表面への打ち水）や気象 条件（湿度条件）の違いと打ち水実施効果についての知 見の蓄積が必要である.

\section{6. まとめ}

散水によるヒートアイランドの緩和を市民の手で行う 事を目的とした社会実験が東京 23 区内で行われた. 著者 等は, 重点地区として大々的に散水が行われた東京都墨 田区東向島 1 3 3 丁目において気温・相対湿度の測定を行 った. その観測結果と数值計算から, 打ち水による気温 低減効果の評価を行った. 本研究により得られた主な知

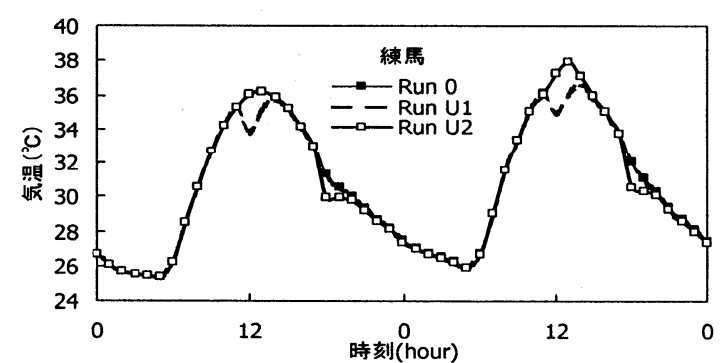

図-15 打ち水の有無による気温の違い（練馬）

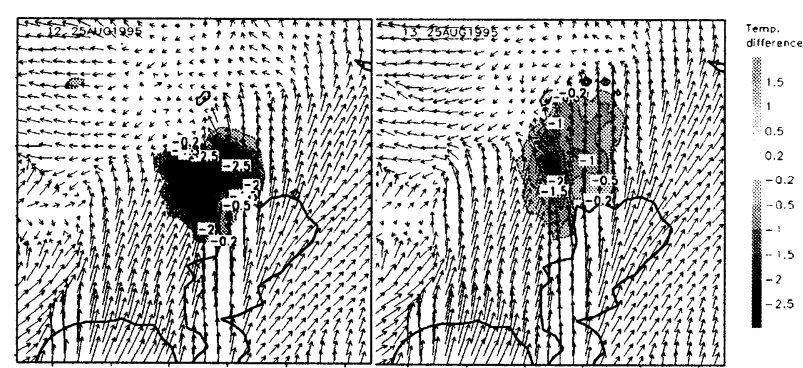

図-17 打ち水の実施による気温の変化

見を以下に示す。

（1）打ち水された個所では，打ち水後に外気温との差 が大きくなっていた. しかし同じ打ち水をされた個所で あっても気温低下量は観測地点によって異なっていた。 打ち水前後において, 打ち水エリア全体の平均外気温差 を比較すると打ち水後の方が $0.5^{\circ} \mathrm{C}$ 程度低かった.

（2）MM5 を用いた数伹計算を行い，打ち水による気温 低減効果の評価を行った. 23 区内の約 $40 \%$ の約 $265 \mathrm{~km}^{2}$ で打ち水を行う条件下で計算を行った. その結果, 打ち 水後の気温低下量は $2 \sim 2.5^{\circ} \mathrm{C}$ 程度であった.

謝辞 : 本実験の実施にあたり，NPO 法人第三回水フォーラム事 務局には多大な協力を得た. 東京都環境科学研究所基盤研究部 の安藤晴夫氏には気象データの提供を受けた.さらに移動観測 では関東学院大学工学部土木工学科宮村研究室の学生の協力を 得た. 合わせてここに記して感謝の意を表す。

\section{参考文献}

1）武若聡・池田駿介・平山孝弘・萱場祐一・財津知亭 : 都市河川による 大気冷却効果一都市河川内外の夏期の熱環境および気象観測一，土木 学会論文集 No.479/II-25, pp.11-20, 1993.

2) 本條 毅・菅原広史・三上岳彦・成田健一・桑田直也 : 新宿御苑のクー ルアイラント効果の実測, 第 14 回環境情報科学論文集, pp273-278.

3）木内豪・神田学・栗橋稔・小林裕明 : 都市内散水による気候緩和効果 の現地観測, 水工学論文集 38 巻, pp381-386, 1994.

4) Grell, G, J. Dudhia and D. Stauffer: ADescription of the Fifth-Generation Penn State/NCAR Mesoscale Model (MM5), NCAR/TN-398+STR, 1994

5) Kinouchi, T. and J. Yoshitani: Simulation of the urban heat island in Tokyo with future possible increases of anthropogenic heat, vegetation cover and water surface, Proc. of the Third Int. Symp. on Environmental Hydraulics with a special theme in Urban Fluid Dynamics, 2001.

6) 土木研究所水理水文チーム: ヒートアイラント現象軽減のための各種 対策の提案とその効果, 平成 14 年度士木研究所講演会講演集, 土木研 究所資料第 3876 号, 2003.

7) Noilhan, J and S. Planton, 1989: A simple parameterization of land-surface processes for meteorological models, Mon. Wea. Rev., 117, 536-549.

8）中野政詩: 土の物質移動学, 東京大学出版会, 187pp. 1991. 